\title{
PENURUNAN BAKTERI TOTAL COLIFORM PADA AIR LIMBAH RUMAH SAKIT TERHADAP PENGARUH LAMA WAKTU PENYINARAN DENGAN SINAR ULTRA VIOLET
}

\author{
Cuti Winarti ${ }^{1)}$ \\ 1) ProgamStudi Teknik Lingkungan Institut Teknologi Yogyakarta \\ email: cutia.winandh@gmail.com ${ }^{1)}$
}

\begin{abstract}
ABSTRAK
Mahluk hidup di dunia ini tanpa terkecuali sangat menggantungkan hidupnya pada air. Pada manusia, air selain sebagai konsumsi makan dan minum juga diandalkan untuk keperluan pertanian, industri dan lain-lain. Makin bertambahnya jumlah penduduk di dunia ini, dengan sendirinya menambah aktivitas kehidupannya yang mau tidak mau menambah pengotoran atau pencemaran air yang pada hakikatnya dibutuhkan. Air limbah rumah sakit adalah seluruh buangan cair yang berasal dari hasil proses seluruh kegiatan rumah sakit yang meliputi kamar mandi, dapur, laundry, ruang operasi dan laboratorium. Air limbah rumah sakit merupakan salah satu sumber pencemaran air yang sangat potensialberdampakpadalingkungan.Dalam sistem pengolahan air limbah RSKIA Sadewa muncul permasalahan pada kualitas air limbah.Hasil uji limbah cair IPAL RSKIA Sadewa masih fluktuatif melebihi baku mutu limbah cair.Berdasarkanhasilujilaboratorium air limbaholehpihak RSKIA SadewapriodeJanuari 2015 - Maret 2016 menunjukkan parameter Total Coliform masih fluktuatif belum memenuhi baku mutu yang ditetapkan.Perludilakukan kontrol terhadap polusi air untuk mencegah penyebaran penyakit melalui air. Dalam pengolahan air limbah rumah sakit perlu adanya pengendalian kualitas air yaitu dengan cara desinfeksi menggunakan radiasi sinar ultra violet. Tujuan dari penelitian ini adalah mengetahui pengaruh desinfeksi dengan penyinaran lampu ultra violet dan merumuskan masalah pengaruh penyinaran lampu ultraviolet terhadap penurunan kadar Total Coliform air limbah Rumah Sakit.

Metode dalam penelitian ini adalah eksperimen dengan analisis laboratorium parameter total coliform dan TSS pada air limbah dengan skala laboratorium.Penelitian dilakukan di Rumah Sakit Khusus Ibu dan Anak Sadewa Yogyakarta dan analisis hasil penelitian dilakukan di laboratorium ITY (STTL "YLH" Yogyakarta) dengan objek penelitian air limbah terolah menggunakan penyinaran dengan ultraviolet 15 watt (panjang gelombang 253,7nm) yang dirangkai sedemikian rupa menggunakan pipa PVC. Variabel bebas dalam penelitian ini adalah penyinaran dengan ultraviolet 15 watt (panjang gelombang 253,7nm) dengan variasi waktu lama penyinaran 0 menit, 3 menit, 6 menit dan 9 menit dalam menurunkan bakteri total coliform. Dari data tersebut diperoleh hasil nilai jumlah penurunan bakteri total coliform, efisiensi dan efektivitas penyinaran.

Hasil analisis laboratorium menunjukkan kadar TSS dan total coliform pada IPAL Rumah Sakit Ibu dan Anak Sadewa belum memenuhi standar baku mutu yang dipersyaratkan. Bakteri Total Coliform sebelum penyinaran didapatkan hasil 2400x103 MPN/100mldan TSS rata-rata 131 mg/L. Rata-rata jumlah total coliform pada waktu penyinaran 0 menit $\left(\mathrm{T}_{1}\right)$ sebanyak $2400 \times 10^{3} \mathrm{MPN} / 100 \mathrm{ml}$, waktu penyinaran 3 menit $\left(\mathrm{T}_{2}\right)$ sebanyak $330 \mathrm{MPN} / 100 \mathrm{ml}$, waktu penyinaran 6 menit $\left(\mathrm{T}_{3}\right)$ sebanyak 157,67 MPN/100ml dan waktu penyinaran 9 menit $\left(\mathrm{T}_{4}\right)$ sebanyak $34 \mathrm{MPN} / 100 \mathrm{ml}$. Hasil efisiensi dengan variasi waktu penyinaran 0 menit $\left(\mathrm{T}_{1}\right)$ dengan debit $\infty$ $2837 \mathrm{ml} /$ menit didapatkan penurunan jumlah total coliform sebesar $0 \%$, waktu 3 menit $\left(\mathrm{T}_{2}\right)$ dengan debit 940 $\mathrm{ml} /$ menit sebesar 99,98\%, waktu 6 menit $\left(\mathrm{T}_{3}\right)$ dengan debit $470 \mathrm{ml} /$ menit sebesar 99,9\%, dan waktu 9 menit $\left(\mathrm{T}_{4}\right)$ dengan debit $310 \mathrm{ml} /$ menit sebesar 99,9\%.Dengan adanya penurunan ini menunjukkan bahwa sinar ultra violet mempunyai kemampuan untuk membunuh bakteri patogen pada air limbah rumah sakit.
\end{abstract}

Kata kunci : Waktu, UV, Total Coliform, Air Limbah Rumah Sakit,

\section{DECREASE OF TOTAL COLIFORM BACTERIA IN HOSPITAL WASTE ON THE EFFECT OF THE LONG TIME OF IRRADIATION WITH ULTRA VIOLET RAYS}

\footnotetext{
ABSTRACT

Every creature in the world are very need an amount of water for alive. The humans, beside to consume as food and beverage, an amount of water are also use to agriculture necessary, industry, ect. The increase a number of citizen population more and more in the world will be followed by various live activities and will increase an amount of water indirectly too. Hospital waste water in an amount of abandon liquid that resulting of hospital activity processes, they come from batchroom, kitchen, laundry, surgical room, and laboratory. Hospital waste water is one of water problem sources that very potential effecting to the environmental. In RSKIA Sadewa waste water treatment system has found troble for it's waste water quality. The RSKIA Sadewa IPAL waste water test result are still fluctuative above waster water grade standard. Based on results of the waste water laboratory by RSKIA Sadewa period on January 2015 - March 2016 shows total coliform
} 
parameter had still fluctuative, not yet according goverment standard regulations. The needed to control its water pollution for prevent the waste borne. In hospital waste water treatment need a water quality control like disinfection by using ultra violet ray radiation. The purposes of the reaserch are to know the side effect of radiation duration with ultraviolet lamp and to formulate the side effect of radiation ultra violet lamp to reduction of total coliform in waste water hospital.

The method of this research is experiment with the parameter laboratory analysis colliform total and TSS to waste water with laboratory scale. This research take at Yogyakarta Mother and Child Specifically Hospital. And the analysis result of research take at ITY (STTL "YLH" Yogyakarta) laboratory with research object waste water treated with 15 watt ultra violet radiation (long phase 253,7 nm), connecting by PVC pipes each other. Independent variables of this research is radiation with ultraviolet 15 watt (long phase 253,7nm) long time variation radiation of 0 minute, 3 minute, 6 minute and 9 minute to reduction colliform total. From the result about it resulted number value Total Coliform bacteria reduction, efficiencies, and radiation effectivities.

Analysis results of laboratory point out value of TSS and Total Coliform at RSKIA Sadewa waste water treatment not yet according goverment standard regulations. The Bacteria Total Coliform before take radiation have get result is $2400 \times 10^{3} \mathrm{MPN} / 100 \mathrm{ml}$ and average of TSS is $131 \mathrm{mg} / \mathrm{L}$. Total average of total coliform on radiation time 0 minute $\left(T_{1}\right)$ is $2400 \times 10^{3} \mathrm{MPN} / 100 \mathrm{ml}$, the radiation time is 3 minute $\left(T_{2}\right)$ there are 330 MPN/100ml total coliform, the radiation time is 6 minute $\left(T_{1}\right)$ there are 157,67 MPN/100ml total coliform, the radiation time is 9 minute $\left(T_{1}\right)$ there are $34 \mathrm{MPN} / 100 \mathrm{ml}$ total coliform. The variation of radiation time each efficiencies 0 minute $\left(T_{1}\right)$ with the debit $\infty 2837 \mathrm{ml} /$ minuteget Total Coliform value reduction is 0\%, 3 minute time $\left(T_{2}\right)$ with the debit of $940 \mathrm{ml} /$ minute is $99,98 \%$, 6 minute time $\left(T_{3}\right)$ with the debit of $470 \mathrm{ml} / \mathrm{minute}$ is $99,9 \%$ and 9 minute time $\left(T_{4}\right)$ with the debit of $310 \mathrm{ml} /$ minute is $99,9 \%$.Base on these reduction, it shown that ultraviolet ray has capability to remove pathogen bacteria in hospital waste water.

\section{Keyword: Time, UV, Total Coliform, Hospital Waste Water}

\section{PENDAHULUAN}

Air limbah atau limbah cair adalah cairan buangan yang tidak terpakai lagi yang berasal dari rumah tangga, perdagangan, perkantoran, industri maupun tempat-tempat umum lainnya yang biasanya mengandung bahan-bahan atau zat-zat yang membahayakan kesehatan atau kehidupan manusia serta mengganggu kelestarian lingkungan hidup.Air limbah rumah sakit adalah seluruh buangan cair yang berasal dari hasil proses seluruh kegiatan rumah sakit yang meliputi kamar mandi, dapur, laundry, ruang operasi dan laboratorium. Air limbah rumah sakit merupakan salah satu sumber pencemaran air yang sangat potensial berdampak pada lingkungan.

Berdasarkan Peraturan Menteri Lingkungan Hidup Republik Indonesia Nomor 7 Tahun 2014 Tentang Baku Mutu Air Limbah, bahwa fasilitas pelayanan kesehatan melakukan pengolahan limbah domestik danlimbah bahan berbahaya dan beracun, wajib memenuhi baku mutu air limbah sebagaimana tercantum dalam Peraturan Menteri ditetapkan menurut peraturan yang berlaku. Atas dasar itu, diperlukan adanya instalasi pengolahan air limbah yaitu bangunan air yang berfungsi mengolah semua buangan yang berasal dari kegiatan di rumah sakit, agar limbah yang akan dibuang ke lingkungan sudah memenuhi baku mutu dan tidak menimbulkan gangguan pada lingkungan sekitar.

Rumah Sakit Khusus Ibu dan Anak Sadewa merupakan salah satu rumah sakit ibu dan anak di Yogyakarta. Rumah sakit ini memiliki instalasi pengolahan air limbah dengan kapasitas $12 \mathrm{~m}^{3}$ per hari. Sistim pengelolaan limbah cair yang digunakan yaitu sistem biofilter aerob. Sistim pengolahan limbah cair yang digunakan terdiri atas bak influen, bak ekualisasi, bak aerobik biofilter model media sarang tawon, bak efluen dan klorinasi.

Dalam sistim pengolahan air limbah RSKIA Sadewa muncul permasalahan pada kualitas air limbah.Hasil uji limbah cair IPAL RSKIA Sadewa masih fluktuatif melebihi baku mutu limbah cair.Berdasarkan hasil uji laboratorium air limbah oleh pihak RSKIA Sadewa periodeJ anuari 2015 Maret 2016 menunjukkan parameter Total Coliform masih fluktuatif belum memenuhi baku mutu yang ditetapkan.

Untuk mencegah penyebaran penyakit melalui air perlu dilakukan control terhadap polusi air.Dalam pengolahan air limbah rumah sakit perlu adanya pengendalian kualitas air. Pengendalian kualitas bakteriologis air limbah rumah sakit salah satunya yaitu dilakukan dengan cara desinfeksi.

Desinfeksi merupakan tahap kritis dalam proses pengolahan air. Desinfeksi dimaksudkan untuk membunuh atau menonaktifkan mikroorganisme patogen di dalam air tersebut (Suprihatin;Suparno, 2013). Desinfeksi menggunakan ultraviolet banyak dipergunakan pada pengolahan air minum baik skala kecil maupun besar. Ultraviolet sangat efektif dalam mendesinfeksi baik terhadap air maupun air buangan (Tjokrokusumo, 1995). 
Tujuan penelitian ini adalah untuk mengetahui pengaruh desinfeksi dengan penyinaran lampu ultra violet dalam penurunan kadar Total Coliform air limbah Rumah Sakit.

\section{TINJAUAN PUSTAKA}

\section{Limbah Rumah Sakit}

Limbah rumah sakit bisa mengandung bermacam-macam mikroorganisme, tergantung pada jenis rumah sakit, tingkat pengolahan yang dilakukan sebelum dibuang dan jenis sarana yang ada (laboratorium, klinik dan lain-lain). Tentu saja dari jenis-jenis mikroorganisme tersebut ada yang bersifat pathogen. Limbah rumah sakit seperti halnya limbah lain akan mengandung bahan-bahan organik dan anorganik, yang tingkat kandungannya dapat ditentukan dengan uji air kotor pada umumnya seperti BOD, COD, pH, mikrobiologik, dan lain-lain. (Arifin.M, 2008 (Online).

Limbah cair yang dihasilkan darisebuah rumah sakit umumnya banyak mengandung bakteri, virus, senyawa kimia, dan obat-obatan yang dapat membahayakan bagi kesehatan masyarakat sekitar rumah sakit, limbah dari laboratorium paling perlu diwaspadai.Potensi dampak air limbah rumah sakit terhadap kesehatan masyarakat sangat banyak maka setiap rumah sakit diharuskan mengolah air limbahnya sampai memenuhi persyaratan standar yang berlaku. Air limbah rumah sakit merupakan salah satu sumber pencemar lingkungan yang sangat potensial.

\section{Desinfeksi}

Desinfeksi adalah proses untuk membunuh bakteri - bakteri pathogen dalam air sehingga diperoleh air yang sehat. Metode desinfeksi secara umum ada 2 yaitu cara fisik dan cara kimia. Desinfeksi secara fisik adalah perlakuan fisik terhadap mikroorganisme yaitu panas dan cahaya yang mengakibatkan matinya mikroorganisme akibat perlakuan fisik tersebut. Air panas hingga titik didihnya akan merusak sebagian besar bakteri. Sinar matahari mempunyai sinar ultra violet yang cukup berperan dalam mematikan mikroorganisme.

Desinfeksi secara fisika dapat dilakukan dengan pemanasan atau perebusan air sampai mendidih (mencapai suhu titik didih) sedangkan dengan sinar ultraviolet sementara ini masih belum banyak digunakan.

\section{Radiasi Ultra Violet}

Radiasi sinar ultra violet adalah radiasi elektromagnetik pada panjang gelombang yang lebih pendek dengan spektrum antara $5-400 \mathrm{~nm}$, menyebabkan kematian mikroorganisme dan tidak meninggalkan sisa radiasi (jadi tidak ada sisa daya desinfeksi) pada air. Radiasi sinar ultra violet telah digunakan sejak pergantian abad ini untuk mendensinfeksi air. (Droste, 1997).

Radiasi sinar ultraviolet dihasilkan oleh lampu khusus (lampu merkuri). Ketika menembus dinding sel mikroorganisme, radiasi UV akan merusak materi genetik sel tersebut dan sel menjadi tidak dapat bereproduksi. Radiasi UV termasuk disinfeksi nonkimia (Suprihatin dan Suparno: 154). Sumber sinar ultraviolet yang digunakan adalah lampu mercury tekanan rendah. Lampu mercury menghasilkan sekitar $85 \%$ output cahaya monokrom pada panjang gelombang $253,7 \mathrm{~nm}$, yang berada pada rentang optimum $(250-270 \mathrm{~nm})$ untuk mematikan mikroorganisme. Untuk menghasilkan energi ultra violet, lampu mengandung uap mercury, energi dibangkitkan dengan eksitesi uap mercury menghasilkan emisi sinar ultra violet.

Radiasi sinar ultra violet dengan panjang gelombang sekitar $254 \mathrm{~nm}$ mempenetrasi dinding sel mikroorganisme dan diadsorpsi oleh bahan seluler termasuk DNA (Deoxyribonucleic acid) dan RNA (ribonucleic acid) sehingga menghalangi replika atau menyebabkan kematian sel. Efektifitas radiasi adalah fungsi langsung dari kuantitas energi atau dosis yang diabsobsi mikroorganisme.

\section{Tabung Penyinaran}

Secara alamiah dengan pemaparan sinar matahari pada panjang gelombang $>290 \mathrm{~nm}$ tentunya akan memakan waktu relatif lama karena sifat bakterisidal dari panjang gelombang > 290nm berkurang jika dibandingkan dengan panjang gelombang $253,7 \mathrm{~nm}$ yang dihasilkan secara buatan yaitu sumber TL-UV atau Neon UV. Dengan tersedia lampu UV buatan (Neon UV) maka tentunya akan dapat diperpendek waktu penyinaran yaitu 76 detik. Untuk memanfaatkan seluruh permukaan lampu dapat dengan cara merendam seluruh bagiannya di dalam air yang ditempatkan di sebuah tabung berdiameter kecil. Ini dimaksudkan agar penyinaran lebih efektif (Anonim, 1988). 


\section{METODOLOGI PENYINARAN}

Penelitian ini dilakukan di Rumah Sakit Khusus Ibu dan Anak Sadewa Yogyakarta dan analisis hasil penelitian dilakukan di laboratorium ITY (STTL "YLH" Yogyakarta) dengan objek penelitian air limbah terolah menggunakan penyinaran dengan ultraviolet 15 watt (panjang gelombang $253,7 \mathrm{~nm}$ ) yang dirangkai sedemikian rupa menggunakan pipa PVC. Variabel bebas dalam penelitian ini adalah penyinaran dengan ultraviolet 15 watt (panjang gelombang $253,7 \mathrm{~nm}$ ) dengan variasi waktu lama penyinaran 0 menit, 3 menit, 6 menit dan 9 menit dalam menurunkan bakteri total coliform.

\section{Alat dan Bahan}

Alat dan bahan yang digunakan dalam penelitian ini adalahTabung penyinaran UV, Stop watch, DrumdanBotol kaca steril.Bahan yang digunakan dalam penelitian ini adalah sampel air limbah terolah Rumah Sakit Khusus Ibu dan Anak Sadewa yang berfungsi sebagai media cair yang mengadung bakteri total coliform

\section{HASIL DAN PEMBAHASAN}

Hasil analisis laboratorium parameter Total Coliform dan TSS (total suspended solid) pada air limbah terolah Rumah Sakit Khusus Ibu dan Anak Sadewa Yogyakarta disajikan pada tabel dibawah ini.

Table 4.1 Hasil Penelitian Parameter Total Coliform

\begin{tabular}{|c|c|c|c|c|c|c|c|}
\hline \multirow[b]{2}{*}{ Waktu } & \multirow[b]{2}{*}{ Sebelum } & \multicolumn{3}{|c|}{ Sesudah Penyinaran } & \multirow{2}{*}{$\begin{array}{l}\text { Total } \\
\text { Obs }\end{array}$} & \multirow{2}{*}{$\begin{array}{c}\text { Rerata } \\
\text { MPN/ } \\
\text { 100ml } \\
\text { Coliform }\end{array}$} & \multirow[b]{2}{*}{$(\%)$} \\
\hline & & $\mathbf{I}$ & II & III & & & \\
\hline 0 Menit & \multirow{4}{*}{$24 \times 10^{5}$} & $24 \times 10^{5}$ & $24 \times 10^{5}$ & $24 \times 10^{5}$ & $72 \times 10^{5}$ & $24 \times 10^{5}$ & 0 \\
\hline 3 Menit & & 240 & 290 & 460 & 990 & 330 & 99,98 \\
\hline 6 Menit & & 210 & 53 & 210 & 473 & 157,67 & 99,99 \\
\hline 9 Menit & & 53 & 36 & 14 & 102 & 34 & 99,99 \\
\hline
\end{tabular}

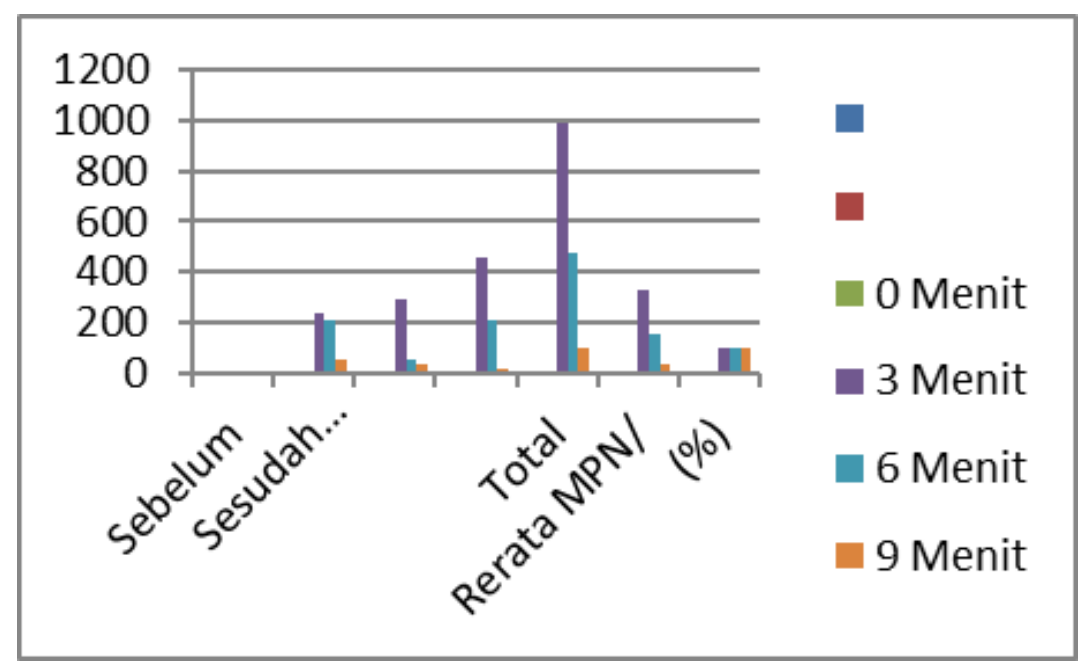

Berdasarkan hasil penelitian dari Tabel 4.1 menunjukkan jumlah bakteri Total Coliform berbeda-beda.Padahasil pengujian awal atau sebelum penyinaran didapatkan jumlah bakteri Total Coliform $2400 \times 10^{3} \mathrm{MPN} / 100 \mathrm{ml}$. Terjadi penurunan rata-rata jumlah total coliform pada waktu penyinaran yaitu 3 menit, 6 menit dan 9 menit.

Untuk hasil efisiensi dengan variasi waktu penyinaran 0 menit $\left(T_{1}\right)$ didapatkan penurunan jumlah total coliform sebesar $0 \%$. Efisiensi waktu penyinaran 3 menit $\left(\mathrm{T}_{2}\right)$ didapatkan penurunan jumlah total coliform sebesar 99,98\%. Efisiensi waktu penyinaran 6 menit $\left(\mathrm{T}_{3}\right)$ didapatkan penurunan jumlah total coliform sebesar $99,9 \%$. Efisiensi waktu penyinaran 9 menit $\left(\mathrm{T}_{4}\right)$ didapatkan penurunan jumlah total coliform sebesar $99,9 \%$. 
Table 4.2 HasilPenelitian Parameter TSS

\begin{tabular}{cccccc}
\hline No & Parameter & Satuan & \multicolumn{3}{c}{ HasilPengujian } \\
\hline 1 & TSS & $\mathrm{mg} / \mathrm{L}$ & 1 & 2 & 3 \\
\hline
\end{tabular}

(Sumber : Data Primer, 2016)

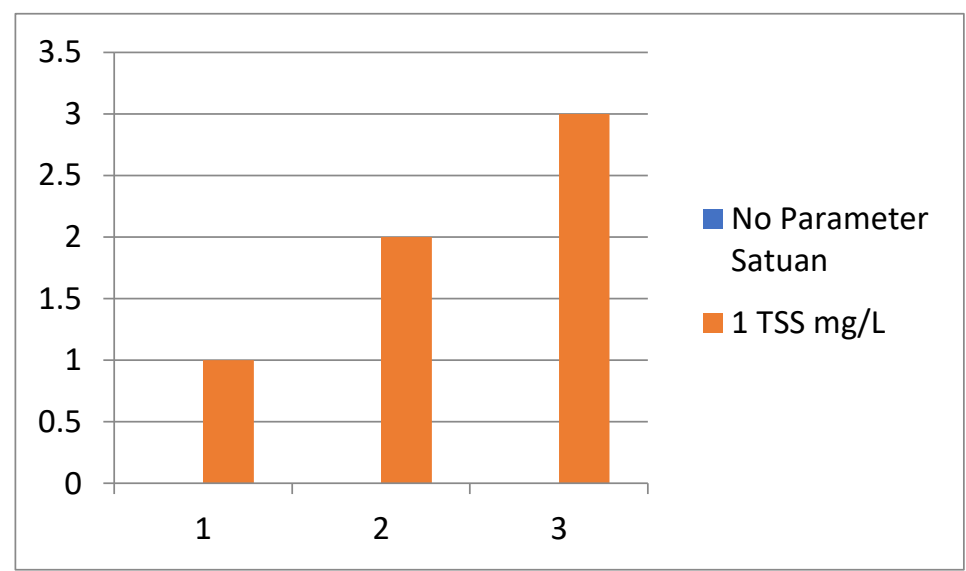

Hasil pemeriksaan terhadap sampel limbah cair Rumah Sakit Ibu Dan Anak Sadewa menunjukkan kadar TSS yang tinggi. Jika dibandingkan dengan peraturan Menteri Lingkungan Hidup dan Kehutanan Nomor 07 tahun 2014 tentang baku mutu air limbah untuk nilai TSS belum memenuhi syarat dengan standar baku mutu yaitu $30 \mathrm{mg} / \mathrm{L}$. Dari Table 4.2 terlihat bahwa hasil pengujian 1 (satu) didapatkan nilai TSS sebesar $144 \mathrm{mg} / \mathrm{L}$, pengujian 2 (dua) didapatkan nilai TSS sebesar $116 \mathrm{mg} / \mathrm{L}$ dan pengujian 3 (tiga) didapatkan nilai TSS sebesar $133 \mathrm{mg} / \mathrm{L}$.

\section{PEMBAHASAN}

Hasil analisis laboratorium menunjukkan kadar TSS dan total coliform pada IPAL Rumah Sakit Ibu dan Anak Sadewa belum memenuhi standar baku mutu yang dipersyaratkan pada Peraturan Menteri Lingkungan Hidup dan Kehutanan Nomor 07 Tahun 2014 tentang baku mutu air limbah bagi usaha dan atau kegiatan fasilitas pelayanan kesehatan. Hal ini memngkinkan disebabkan adanya factor system pengolahan air limbah cair rumah sakit yang kurang maksimal.Kekeruhan yang ada dalam air buangan disebabkan oleh berbagaim acam suspended solid yang ada. Limbah cair dengan kadar TSS yang tinggi bila dibuang ke lingkungan tanpa melalui pengolahan dapat mengganggu biota air dan akhirnya mengganggu pendegradasian senyawa organik.

Untuk menurunkan kadar TSS diperlukan pengolahan salah satunya pengolahan biologis yaitu membuat bak sedimentasi pada IPAL Rumah Sakit Khusu Ibu dan Anak Sadewa dengan mengatur waktu pengendapan sehingga flok pada air limbah akan turun secara gravitasi dan terkumpul di dasar bak. Pembubuhan tawas atau klor pada airlimbah juga mampu mengikat koloid atau padatan tersuspensi dalam air limbah untuk mengurangi kadar TSS.

Dengan adanya penurunan ini menunjukkan bahwa sinar ultra violet mempunyai kemampuan untuk membunuh bakteri patogen pada air limbah rumah sakit. Radiasi sinar ultra violet akan menyinari dinding sel dan diabsirbsi oleh materi sel termasuk DNA dan RNA sehingga akan mencegah repkikasi atau penggandaan diri menyebabkan kerusakan sel (lisis), menyebabkan perubahan pada meteri organik dan menyebabkan sel mati.

Pada penelitian ini hipotesis telah membuktikan bahwa penyinaran menggunakan neon ultraviolet (UV) 15 watt dengan panjang gelombang 253,7 nm dapat menurunkan kadar bakteri Total Coliform pada air Limbah Rumah Sakit Khusus Ibu dan Anak Sadewa dengan variasi waktu kontak 6 menit, sehingga dapat memenuhi baku mutu air limbah rumah sakit pada parameter bakteriologis. Berarti dapat disimpulkan bahwa penyinaran dengan menggunakan neon UV efektif untuk membunuh bakteri total coliform pada air limbah rumah sakit.

\section{KESIMPULAN}

1. Lampu neon ultra violet 15 watt dengan Panjang gelombang $253,7 \mathrm{~nm}$ mampu menurunkan bakteri total coliform pada sampel air limbah Rumah Sakit Khusus Ibu dan Anak Sadewa Yogyakarta. 
2. Variasi waktu penyinaran air limbah rumah sakit dengan lampu ultra violet 15 watt yang mampu menurunkan bakteri total coliform yaitu waktu 3 menit, 6 menit, dan 9 menit.

3. Efisiensi waktu penyinaran lampu ultraviolet 15 watt untuk menurunkan kadar Total Coliform air limbah RSKIA Sadewa yaitu waktu 3 menit dengan debit $940 \mathrm{ml} /$ menit sebesar 99,98\%, waktu 6 menitd engan debit $470 \mathrm{ml} /$ menit sebesar 99,99\% dan waktu 9 menit dengan debit $310 \mathrm{ml} / \mathrm{menit}$ sebesar 99,99\%.

4. Efektivitas penyinaran dengan lampu ultra violet 15 watt telah mampu menurunkan jumlah bakteri total coliform dalamwaktu 3 menit dengan efisiensi mencapai 99,98\%.

5. Penurunan jumlah bakteri total coliform telah memenuhi standar baku air mutu yang dipersyaratkan pada Peraturan Menteri Lingkungan Hidup dan Kehutanan Nomor 07 Tahun 2014 tentang baku mutu air limbah bagi usaha dan atau kegiatan fasilitas pelayanan kesehatan.

6. Kadar TSS air limbah RSKIA Sadewa belum memenuhi standar baku mutu yang dipersyaratkan pada Peraturan Menteri Lingkungan Hidup dan Kehutanan Nomor 07 Tahun 2014 tentang baku mutu air limbah bagi usaha dan atau kegiatan fasilitas pelayanan kesehatan.

\section{DAFTAR PUSTAKA}

Anonim, 1988, laporan akhir karya ilmiah, jurusan teknik lingkungan ITB, Bandung

Asmadi \& Suharno, 2012, Dasar - dasar Teknologi Pengolahan Air Limbah, Yoyakarta, Gosyen Publishing.

Asmadi, 2013, Pengelolaan Limbah Medis Rumah Sakit, Yogyakarta, Gosyen Publishing

Asmadi, DKK, 2011, teknologi pengolahan air minum, Yogyakarta, Gosyen Publishing

Arifin, 2008, Jurnal: http://www.pontianakpost.com Pengaruh Limbah Rumah Sakit Terhadap Kesehatan, Jakarta.

Chandra Budiman, 2014, Pengantar Kesehatan Lingkungan, Jakarta, Buku Kedokteran EGC.

Depkes RI, 2004. Keputuan Menteri Kesehatan No. 1204/MENKES/SK/2004 tentang Persyaratan Kesehatan Lingkungan Rumah Sakit, Jakarta : Depkes RI

Depkes RI, 1995. Keputuan Menteri Lingkungan Hidup No. 58/MENLH/12/1995 tentang Baku Mutu Limbah Cair Bagi Rumah Sakit, Jakarta: Depkes RI.

Djohan \& Halim, 2013, pengelolaan limbah rumah sakit, Jakarta, Salemba Medika

Droste R,L, 1997, Theory Practice of Water and wastewater treatment, Jhon Wiley \& sons Inc, Singapore

Ginting Perdana, 2007. Sistem Pengelolaan Lingkungan dan Limbah Industri, Bandung : CV. Yrama Widya.

Gordon, 1968, Water and Waswater Engineering, Volume 2, New York

Peraturan Menteri Lingkungan Hidup Republik Indonesia Nomor 5 Tahun 2014 Tentang Baku Mutu Air Limbah.

Keputusan Menteri Kesehatan Republik Indonesia Nomor : 1204 / MENKES / SK / X /2004 Tentang Persyaratan Kesehatan Lingkungan Rumah Sakit.

McGhee, 1991, Water Supply and Sewarage, Mc Graw-Hill Sixt Edition, New York.

Mahida, 1993, pencemaran air dan pemanfaatan limbah industri, Jakarta Utara, PT Raja Grafindo Persada

Ronald,1997, Theory and Practice of Water and wastwater Treatment, John Wiley \& Sons Inc, New York.

Said, 2003, teknologi pengolahan air limbah secara anaerob dan aerobmenggunakan biofilter, BPPT, Jakarta

Slamet, Juli Soemirat. 1996, Kesehatan Lingkungan, Yogyakarta: Gajah Mada University Press.

SudartoAdi, 1999,Pengaruh Lama WaktuPenyinaranDengan Neon Ultra Violet TerhadapPenurunanBakteriColitinjaDalam Media Cair, Yogyakarta, Prodi

TeknikLingkungan, SekolahTinggiTekikLingkungan.

Suprihatin, dan Suparno , 2013, teknologi proses pengolahan air, Bogor, IPB Press

Tchhobanoglous, 1991,Wastewater Engineering Treatment, Disposal, and Reuse/Metcalf \&Eddy,Inc.,3rd Edition, McGraw-Hill, Inc.New York.

Tchbanoglous, 1983, Environmental Engineering, Mc Graw-Hill, New York.

Tjokrokusumo, Pengantar Enjiniring Lingkungan, Sekolah Tinggi Teknik Lingkungan "YLH", Yogyakarta, 1999. 